\title{
MATERIAL PROPERTIES OF HERITAGE WROUGHT STEEL STRUCTURE BASED ON TESTS
}

\author{
KAREL JUNG, JANA MARKOVA, PETR POKORNY AND MIROSLAV SYKORA \\ Klokner Institute, Czech Technical University in Prague, Czech Republic
}

\begin{abstract}
Many heritage structures do not fulfil requirements of present standards. Decisions about adequate construction interventions should be based on complex assessment of structural reliability. Such an assessment should take into account new utility plans, actual material properties and environmental influences, including degradation processes, satisfactory past performance and advanced modelling reflecting properties of historic materials that are often distinctly different from those assumed for current construction materials.

The submitted contribution focuses on reliability assessment of balcony girders of the Estates Theatre in Prague, listed as a Czech national heritage monument. Preliminary reliability assessment, based on conservative recommendations of standards for existing structures, reveals that the resistance of the wrought steel girders from the 19th century is insufficient. This is why a series of non-destructive tests supplemented by a single tensile test are performed in order to obtain information about the homogeneity of the historic material, its strength and modulus of elasticity. The results of the tests are then evaluated using statistical methods. The design values of basic variables are estimated, considering uncertainties in material properties, geometry and resistance models. In addition, chemical analysis is performed to identify material composition and verify a type of historic steel.

Keywords: Brinell hardness test, heritage structures, homogeneity; material properties, reliability assessment, statistical approach, wrought steel
\end{abstract}

\section{INTRODUCTION}

Load-bearing structures of numerous heritage buildings are made of historic metallic materials. Particularly in the 19th and early 20th centuries, wrought steel and cast iron became popular construction materials [1]. It has been recognized that such structures often fail to fulfil requirements of present codes of practice $[2,3]$. Decisions about adequate construction interventions should be based on the complex assessment of a structure considering actual material properties, environmental influences and satisfactory past performance [4]. A key step of this assessment is modelling of resistance of load-bearing members [5].

The submitted contribution is focused on reliability assessment of the balcony girders of the Estates Theatre in Prague under rehabilitation, one of the oldest European theatres, listed as a Czech national heritage monument (Fig. 1). The girders were fabricated in the 19th century; a type of the metallic material is unknown.

Preliminary reliability assessment, based on conservative recommendations of current standards for existing structures, reveals that resistance of the steel girders is insufficient. Reliability analysis of heritage structures have to treat numerous uncertainties related to lack of information about material properties, construction procedures, structural system behaviour, and so on. Focusing on the first aspect, a number of destructive tests (DTs) that are needed to gain credible information on material properties is mostly limited by the requirements on cultural heritage value protection. This is why a few DTs only are commonly supplemented with a series of non-destructive tests (NDTs). 


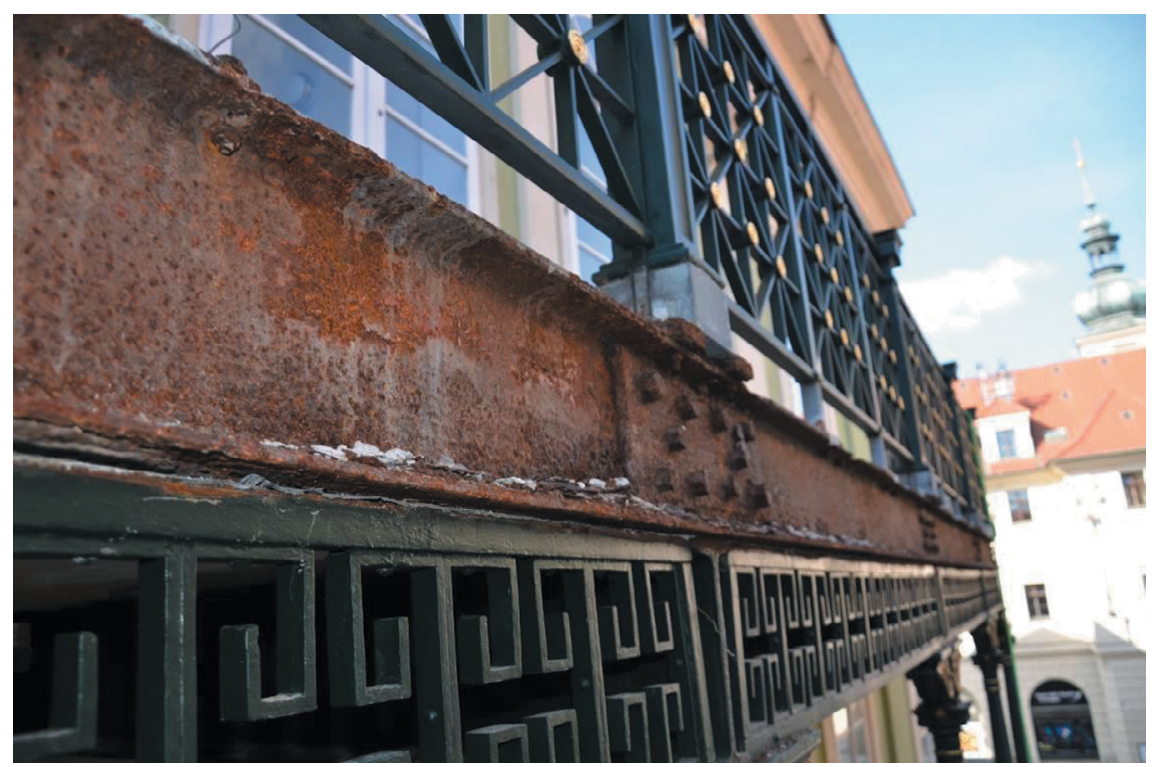

Figure 1: A view of the balcony of the Estates Theatre in Prague.

The information given in Annex D of EN 1990 [6] provides a first insight into specification of a minimum number of tests. When coefficient of variation of the material property under consideration, $V_{X}$, or its conservative estimate is known, a characteristic value of the material property, $X_{k}$, can be assessed from one test result only. In case of unknown $V_{X}$, no prior knowledge is available and at least three tests are needed.

For the balconies under study, a cultural heritage protection authority has approved to take only one specimen for destructive testing. The submitted contribution illustrates how a characteristic value and partial factor for material properties can be estimated under such conditions. One destructive tensile test is supplemented by

- Non-destructive hardness Brinell tests to verify homogeneity of a material across several balcony girders

- Chemical analysis to confirm a type of the material

- Prior information based on previous experience with historical steel materials.

Characteristic value and partial factor are then estimated in accordance with the principles of EN 1990 [6], ISO 13822 [7] and the Czech standard for assessment of existing structures CSN 730038 [8].

Note that the CIB guide [9] for the structural rehabilitation of heritage buildings indicates that a key issue of historic steel structures is corrosion. This has been addressed in the case study as well; however, information on this is beyond the scope of the submitted contribution.

\section{MATERIAL HOMOGENEITY VERIFICATION}

Results of Brinell hardness tests are taken into account to verify homogeneity of the material. Measurements are taken at ten locations; eight hardness tests are carried out at each of the locations. Figure 2 displays the histogram of strengths based on NDTs. A conversion factor is applied to make the NDT estimates consistent with the tensile strength obtained by DT. 


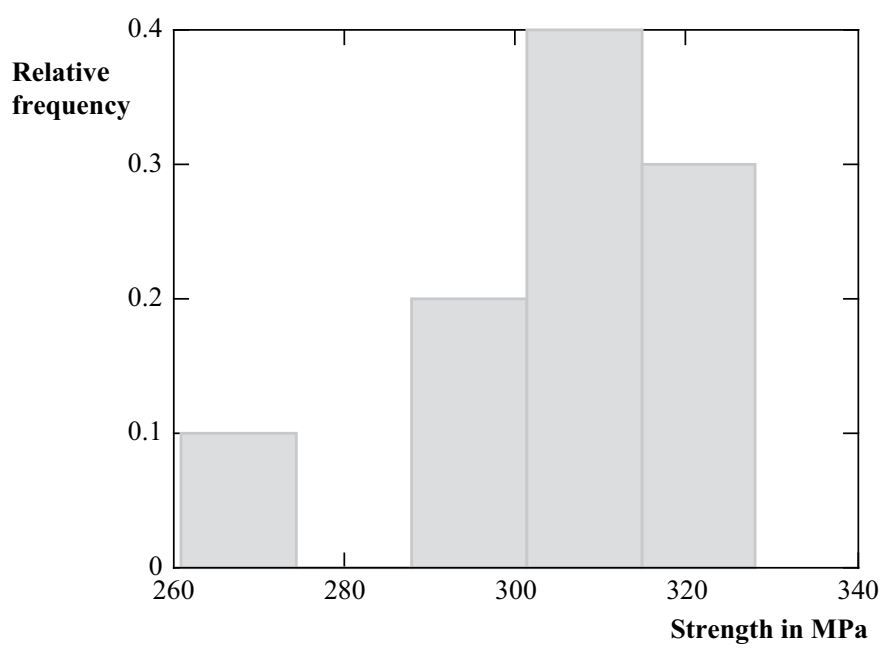

Figure 2: Histogram of strengths based on NDTs.

Grubb's test [10] indicates that the sample likely contains no outlier and extreme observations can result from random variability. This is why the wrought steel is considered as homogenous across all the inspected girders.

\section{INPUT DATA AND BASIC ASSUMPTIONS}

Tensile test (Fig. 3) leads to the following basic material properties:

- Yield strength: $f_{\mathrm{y}}=275 \mathrm{MPa}$ obtained for strain of $0.2 \%$

- Ultimate strength: $f_{\mathrm{u}}=304 \mathrm{MPa}$

- Ductility $\varepsilon_{\mathrm{u}}=5.1 \%$

- Modulus of elasticity $E=127 \mathrm{GPa}$

These values well correspond to the general information provided by the report of the European Joint Research Centre [11], where the following ranges are indicated for wrought steel: $f_{\mathrm{y}} \approx 220-310 \mathrm{MPa} ; f_{\mathrm{u}} \approx 280-400 \mathrm{MPa}$ and $\varepsilon_{\mathrm{u}} \approx 5-20 \%$. These observations are also in agreement with an experience gained in the Czech Republic - structures constructed before 1894 were mostly made from wrought steel or cast iron, CSN 730038 [8]. Table 1 provides an overview of information about properties of historical steels. This evidence thus clearly suggests that the material can be classified as wrought steel.

Material strength based on NDTs exceeds that based on a tensile test by about 50\%, which is common for historic steels [12]. This is why the NDT estimates are hereafter considered as indicative only, and wrought steel properties are assessed on the basis of the tensile test and general experience with historical structures.

\section{CHARACTERISTIC VALUE}

A two-parameter lognormal distribution [10] provides commonly an appropriate model for strengths of metallic materials including historic steels [3]. A characteristic value is then estimated as follows [6]:

$$
X_{k}=\exp m_{\ln X}-k_{n} s_{\ln X} \approx \exp m_{\ln X}-k_{n} V_{X}
$$




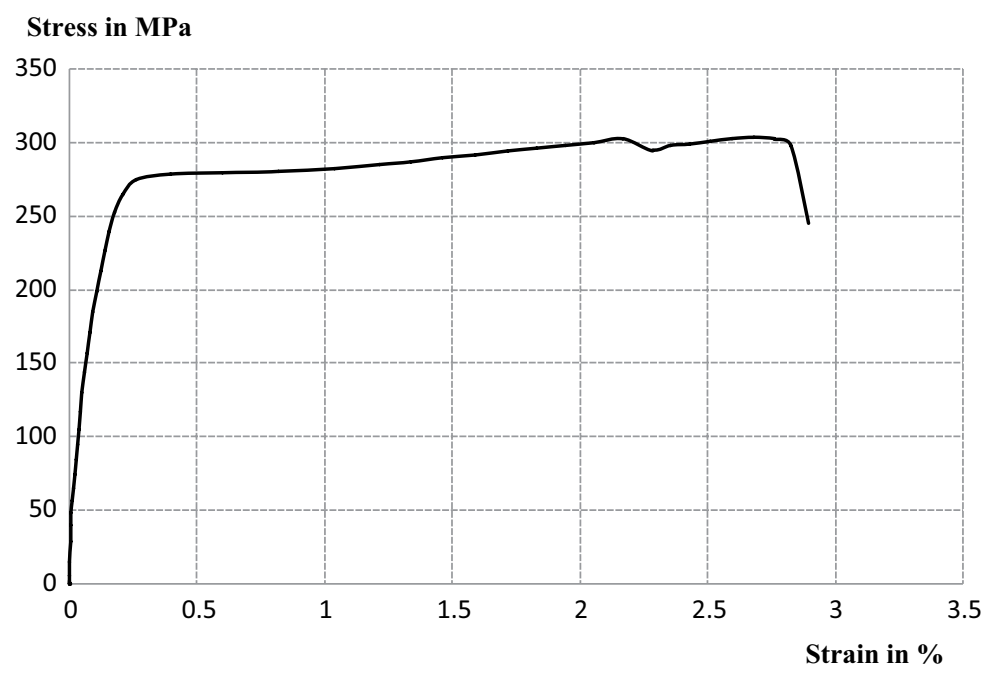

Figure 3: Stress and strain diagram of wrought steel of the beam.

where $m_{\ln X}=\sum_{i} \ln \left(X_{i}\right) / n$ (for $i=1, \ldots, n$ and number of tests $n$ ) and standard deviation $s_{\ln X}$ corresponds approximately to the coefficient of variation $V_{X}$.

CSN 730038 [8] recommends for cast iron strength a coefficient of variation in the range $V_{\mathrm{fu}} \approx 0.1-0.15$. As variability of wrought steel strength is commonly lower than that of cast iron [3], the middle value of this interval, $V_{\mathrm{fu}}=0.125$, is deemed to provide a reasonably conservative estimate. The same value is taken into account for yield strength of wrought steel, $V_{\text {fy }}=0.125$.

Following the guidance of Annex D of EN 1990 [6] for 'known $V_{X}$ ' - see eqn (1), the characteristic values of wrought steel strengths are estimated on the basis of one tensile test as follows:

Table 1: Material properties of historical steels.

\begin{tabular}{|c|c|c|c|c|}
\hline Material & Chemical composition & Use & $\begin{array}{l}\text { Material properties } \\
(f \text { in } \mathrm{MPa}, \text { modulus of } \\
\text { elasticity } E \text { in } \mathrm{GPa})\end{array}$ & Ref. \\
\hline Cast iron & $\begin{array}{l}\mathrm{C} \approx 2.0-4.0 \%, \mathrm{Mn} \approx \\
0.2-1.2 \%, \mathrm{Si} \approx 0.3-3.0 \% \\
\mathrm{~S} \leq 1.2 \%, \mathrm{P} \leq 1.0 \%\end{array}$ & & $f_{\mathrm{u}} \approx 90-135 ; \varepsilon_{\mathrm{u}} \approx 0 \%$ & {$[11]$} \\
\hline Wrought steel & $\begin{array}{l}\mathrm{C} \leq 0.8 \%, \mathrm{Mn} \leq 0.4 \% \\
\mathrm{~S} \leq 0.04 \%, \mathrm{P} \leq 0.6 \%\end{array}$ & $\begin{array}{l}\text { Load-bearing } \\
\text { structures }\end{array}$ & $\begin{array}{l}f_{\mathrm{y}} \approx 220-310 ; f_{\mathrm{u}} \approx \\
280-400 ; \varepsilon_{\mathrm{u}} \approx 5-20 \%\end{array}$ & \\
\hline $\begin{array}{l}\text { Wrought steel } \\
\text { (produced } \\
\text { before 1900) }\end{array}$ & NA & & $\begin{array}{l}\text { Tensile strength } f_{\mathrm{yd}}= \\
180\end{array}$ & \\
\hline
\end{tabular}


Table 1: Continued

\begin{tabular}{|c|c|c|c|c|}
\hline Material & Chemical composition & Use & $\begin{array}{l}\text { Material properties } \\
(f \text { in } \mathrm{MPa}, \text { modulus of } \\
\text { elasticity } E \text { in } \mathrm{GPa})\end{array}$ & Ref. \\
\hline Cast iron & NA & $\begin{array}{l}\text { All structural } \\
\text { members } \\
\text { except for } \\
\text { columns }\end{array}$ & $\begin{array}{l}\text { Design value of tensile } \\
\text { strength } 30, \text { design } \\
\text { value of compressive } \\
\text { strength } 65, E=100\end{array}$ & [8] \\
\hline Cast iron & NA & Columns & $\begin{array}{l}\text { Design tensile strength } \\
45 \text {, design compressive } \\
\text { strength } 100, E=100\end{array}$ & \\
\hline $\begin{array}{l}\text { White iron } \\
\text { of very good } \\
\text { quality, } \\
\text { completely } \\
\text { fibrous }\end{array}$ & $\begin{array}{l}\mathrm{S} \approx 0.25-0.5 \%, \mathrm{P} \approx \\
1.5-2 \%\end{array}$ & $\begin{array}{l}\text { Bridges, truss } \\
\text { girders }\end{array}$ & $\begin{array}{l}f_{\mathrm{u}} \approx 330-360 ; \varepsilon_{\mathrm{u}} \\
\approx 6-9 \%\end{array}$ & \\
\hline $\begin{array}{l}\text { White iron } \\
\text { of ordinary } \\
\text { quality, } \\
\text { half-granular, } \\
\text { half-fibrous }\end{array}$ & $\begin{array}{l}\mathrm{S} \approx 0.25-0.5 \%, \mathrm{P} \approx \\
2-2.5 \%\end{array}$ & $\begin{array}{l}\text { Girders, } \\
\text { angle, } \\
\text { T-profile }\end{array}$ & $\begin{array}{l}f_{\mathrm{u}} \approx 250-320 \\
\varepsilon_{\mathrm{u}} \approx 4-5 \%\end{array}$ & [13] \\
\hline $\begin{array}{l}\text { Grey cast } \\
\text { iron of high } \\
\text { quality }\end{array}$ & $\mathrm{C}<0.3 \%$ & $\begin{array}{l}\text { Bridges, truss } \\
\text { roof girders }\end{array}$ & $\begin{array}{l}f_{\mathrm{u}} \approx 330-500 \\
\varepsilon_{\mathrm{u}} \approx 20-31 \%\end{array}$ & \\
\hline $\begin{array}{l}\text { Grey cast iron } \\
\text { (Germany) }\end{array}$ & NA & Columns & $\begin{array}{l}f_{\mathrm{u}} \approx 111-125(448- \\
462 \text { compressive }) \\
E \approx 96-111\end{array}$ & [14] \\
\hline $\begin{array}{l}\text { Grey cast iron } \\
\text { (UK) }\end{array}$ & NA & Buildings & $\begin{array}{l}f_{\mathrm{u}} \approx 75-160 \text { with mean } \\
124(\text { compressive } \\
750) ; E \approx 91\end{array}$ & {$[15$,} \\
\hline Cast iron (UK) & NA & & $\begin{array}{l}f_{\mathrm{u}} \approx 124(\text { compressive } \\
590-780) ; E \approx 66-93\end{array}$ & 16] \\
\hline
\end{tabular}

$$
\begin{aligned}
& f_{\mathrm{yk}} \approx \exp [\ln 275-2.31 \times 0.125]=206 \mathrm{MPa} \\
& f_{\mathrm{uk}} \approx \exp [\ln 304-2.31 \times 0.125]=228 \mathrm{MPa}
\end{aligned}
$$

\section{PARTIAL FACTORS AND DESIGN VALUES}

Whereas the estimate of a characteristic value may be based on a limited number of tests, the partial factor is commonly based on previous general experience with reliability assessments of steel structures and with uncertainties in modelling, material properties and geometry variables [6]. CSN 730038 [8] provides the following relationship:

$$
\gamma_{\mathrm{M}}=\exp \left(-1.645 V_{X}\right) / \exp \left(-\alpha_{R} \beta V_{R}\right)
$$


where $\alpha_{R}=0.8$ denotes the sensitivity factor for resistance and $\beta=3.8$ the target reliability index $[6,7]$ and $V_{R}$ is the coefficient of variation of resistance. The target level corresponds to moderate failure consequences, taking into account the effect of cultural heritage protection aspects [3].

It can be considered that resistance of a steel load bearing member $R$ is linearly dependent on its strength $X$, geometrical properties geo (e.g. sectional areas for failure modes related to compressive or shear forces; in the study under consideration sectional modulus for flexural resistance) and resistance model uncertainty $\xi$ :

$$
R=\xi \times \text { geo } \times X
$$

Coefficient of variation of resistance - see eqn (3) - can then be estimated as follows:

$$
V_{R} \approx \sqrt{ }\left(V_{X}^{2}+V_{\mathrm{geo}}^{2}+V_{\xi}^{2}\right)
$$

Table 2 provides an overview of coefficients of variation for historic metallic materials [8] and justification of the values adopted herein.

Using eqns (3) and (5), partial factors for yield and ultimate strengths become

$$
\begin{aligned}
& V_{R} \approx \sqrt{ }\left(0.125^{2}+0.05^{2}+0.05^{2}\right)=0.144 \\
& \gamma_{\mathrm{M}} \approx \exp (-1.645 \times 0.125) / \exp (-0.8 \times 3.8 \times 0.144)=1.26
\end{aligned}
$$

\begin{tabular}{|c|c|c|c|}
\hline Symbol & $\begin{array}{l}\text { Coefficient of } \\
\text { variation[8] }\end{array}$ & $\begin{array}{l}\text { Adopted } \\
\text { value }\end{array}$ & Justification \\
\hline$V_{X}$ & $0.10-0.15$ & 0.125 & $\begin{array}{l}\text { The recommended range is deemed to pro- } \\
\text { vide conservative estimates for homogenous, } \\
\text { high-quality wrought steel [3]. In the absence } \\
\text { of structure-specific experimental data, a } \\
\text { middle value of the interval is taken into } \\
\text { account. }\end{array}$ \\
\hline$V_{\text {geo }}$ & $0.05-0.10$ & 0.05 & $\begin{array}{l}\text { Dimensions are verified in situ; the lower } \\
\text { bound is thus considered. }\end{array}$ \\
\hline$V_{\xi}$ & $0.05-0.10$ & 0.05 & $\begin{array}{l}\text { The lower bound applies for flexural and } \\
\text { shear resistance of steel girders }[17,18] \text {. The } \\
\text { adopted model for } \xi \text { is deemed to be some- } \\
\text { what conservative as: } \\
\text { - Equation (3) is based on the assumption of } \\
\text { an unbiased model and yield (not ultimate) } \\
\text { strength is to be applied in reliability } \\
\text { analysis. } \\
\text { - Reliability is not affected by the loss of } \\
\text { stability. }\end{array}$ \\
\hline
\end{tabular}

Table 2: Coefficients of variation for historic metallic materials [8]. 
and the design values are obtained from the characteristic values in eqn (2) as follows:

$$
\begin{gathered}
f_{\mathrm{yd}} \approx f_{\mathrm{yk}} / \gamma_{\mathrm{M}}=206 / 1.26=163 \mathrm{MPa} \\
f_{\mathrm{ud}} \approx f_{\mathrm{uk}} / \gamma_{\mathrm{M}}=228 / 1.26=181 \mathrm{MPa}
\end{gathered}
$$

It is interesting to observe that CSN 730038 [8] indicates a design value of yield strength of wrought steel for structures constructed before 1900 as $f_{\mathrm{yd}} \approx 180 \mathrm{MPa}$. Design values for cast iron are, however, much lower (30-45 MPa).

Annex D of EN 1990 [6] allows estimating a design value directly from one test ( 'known $V_{X}$ '):

$$
\begin{aligned}
& f_{\mathrm{yd}} \approx \exp [\ln (275)-4.63 \times 0.125]=154 \mathrm{MPa} \\
& f_{\mathrm{ud}} \approx \exp [\ln (304)-4.63 \times 0.125]=170 \mathrm{MPa}
\end{aligned}
$$

Model and geometrical uncertainties can be easily covered by a partial factor $\gamma_{R \mathrm{~d}} \approx 1.05$ $[17,18]$ :

$$
\begin{gathered}
f_{\mathrm{yd}} \approx 154 / 1.05=147 \mathrm{MPa} \\
f_{\mathrm{ud}} \approx 170 / 1.05=162 \mathrm{MPa}
\end{gathered}
$$

These values are about 10\% lower than those in eqn (7). However, EN 1990 [6] generally recommends estimating a design value on the basis of the ratio of a characteristic value and partial factor and thus the values given in eqn (7) are recommended for reliability verification.

\section{CHEMICAL ANALYSIS}

To utilize fully the specimen taken from the balcony girder and confirm the assumption concerning the type of the construction material, metallurgical analysis is conducted to identify individual phases in an unknown ferrous alloy. Figure 4 displays two cross sections of the specimen obtained by a scanning electron microscope. A layered structure with anisotropic localized cracks in the longitudinal direction is observed whilst no intermediate phase $\mathrm{Fe}_{3} \mathrm{C}$ (cementite - characteristic for modern steels) and no graphite in any form (typical for graphite cast ferrous alloys) are detected. These observations clearly indicate that the material under investigation should be classified as wrought steel.

To support this conclusion, chemical composition of the alloy is investigated by an X-ray fluorescence analyser (XRF) and an optical emission spectrometry excited by glow discharge (GDOS). XRF provides the information on the content of minor elements typical for ferrous alloys and GDOS identifies carbon content. A considerable amount of impurities measured by the XRF technique (Table 3) and a very low carbon content (less than $0.01 \mathrm{wt} . \%$; see Fig. 5) measured by GDOS conclusively point to wrought steel (compare also with the information in Table 2). 

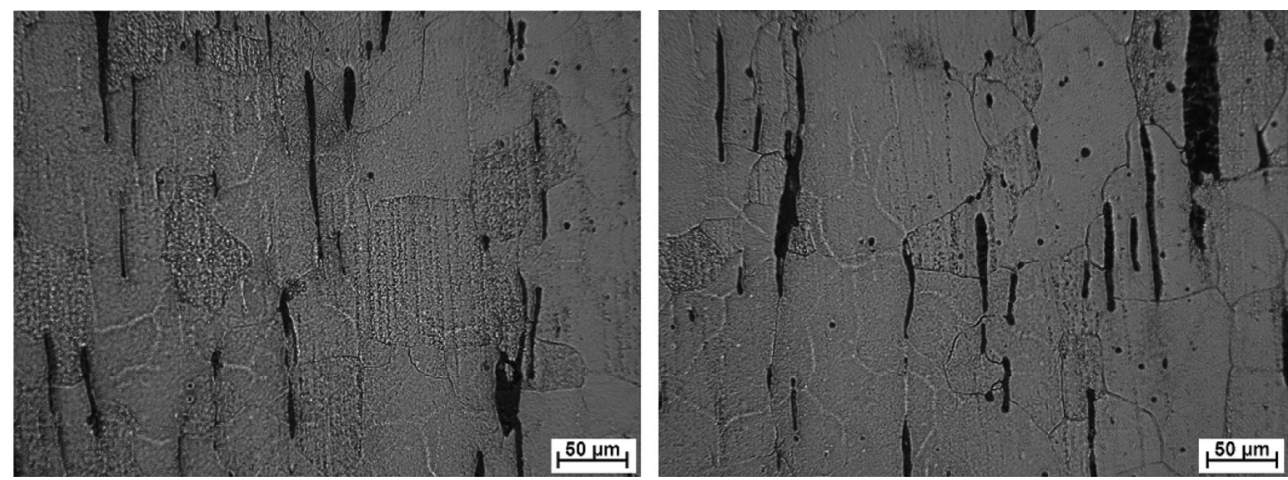

Figure 4: Two cross sections of the specimen obtained by a scanning electron microscope.

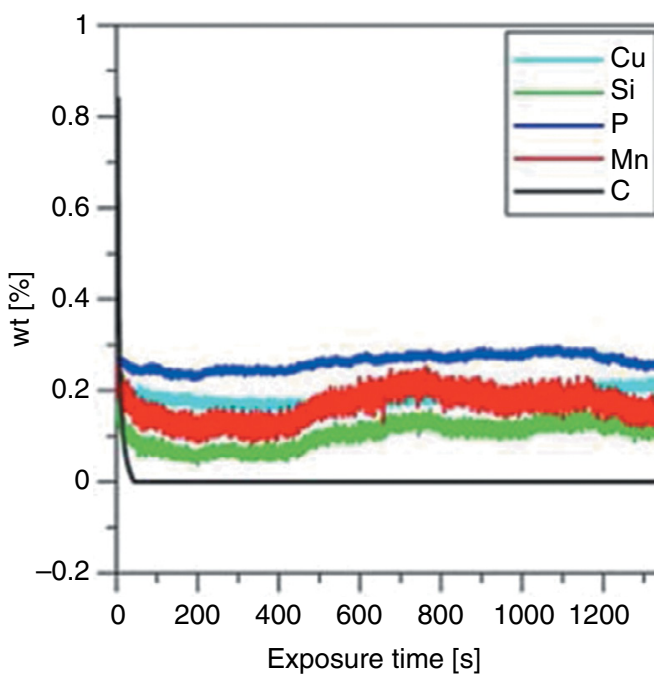

Figure 5: Elemental profile analysis by GDOS.

Table 3: Results of the XRF analysis.

\begin{tabular}{lccc}
\hline Element & Content (wt.\%) & Element & Content (wt.\%) \\
\hline $\mathrm{Mg}$ & 0.023 & $\mathrm{Mn}$ & 0.266 \\
$\mathrm{Al}$ & 0.030 & $\mathrm{Fe}$ & 98.875 \\
$\mathrm{Si}$ & 0.414 & $\mathrm{Cu}$ & 0.157 \\
$\mathrm{P}$ & 0.125 & $\mathrm{Zn}$ & 0.013 \\
$\mathrm{~S}$ & 0.022 & $\mathrm{As}$ & 0.030 \\
$\mathrm{Ca}$ & 0.016 & & \\
\hline
\end{tabular}




\section{CONCLUDING REMARKS}

The presented study reveals that the reliability assessment of heritage structures is a complex issue. Numerous uncertainties affecting estimated resistance can be treated by statistical approaches and a semi-probabilistic verification method that is suitable for practical applications.

The case study, focused on wrought steel balconies of a heritage building, indicates the following:

1. Brinell hardness tests can be used to verify the homogeneity of historic steel materials. However, such tests should always be supplemented by tensile tests to provide credible information on which a material model for reliability verification can be established.

2. Unique DT can be used in combination with several NDTs to assess strength of wrought steel balconies. In such a case, classification of the structural material should be supported by a chemical analysis.

3. Values of material properties, recommended in standards, seem to be overly conservative, and therefore, it is advised to specify properties of historic metallic materials by tests. In the presented case study, the design value of material strength based on measurements exceeds the recommended value given in the Czech standard CSN 730038 for existing structures (a National Annex to ISO 13822) by about three times, i.e. by $\sim 100 \mathrm{MPa}$.

\section{ACKNOWLEDGEMENTS}

This study is an outcome of the research project NAKI DG16P02M050 'Optimisation of observations and assessment of heritage structures', supported by the Ministry of Culture of the Czech Republic.

\section{REFERENCES}

[1] Zeman, L. \& Pospíšil, M., Spa technology with steel - Cast-iron structures in Karlovy Vary. Architektura a Urbanizmus, 48(3-4), pp. 270-285, 2014.

[2] Sykora, M., Holicky, M. \& Diamantidis, D., Probabilistic updating in the reliability assessment of industrial heritage structures. Heron, 59(2/3), pp. 9, 2015.

[3] Sykora, M., Holicky, M., Markova, J. \& Senberger, T., Probabilistic Reliability Assessment of Existing Structures (Focused on Industrial Heritage Buildings), Czech Technical University in Prague, CTU Publishing House: Prague, pp. 108, 2016.

[4] Holicky, M. \& Sykora, M., Reliability assessment of heritage architecture (invited contribution). Proc. STREMAH 2013, eds. C.A. Brebbia, WIT Press: Ashurst Lodge, pp. 87-98, 2013.

[5] Markova, J., Holicky, M., Jung, K., Podstawka, A. \& Bures, V., Reliability assessment of cast-iron heritage structures. Proc. ESREL 2014, eds. T. Nowakowski, M. Mlynczak, A. Jodejko-Pietruczuk \& S. Werbinska-Wojciechowska, Taylor and Francis/ Balkema: Leiden, pp. 2201-2205, 2015.

[6] EN 1990, Eurocode - Basis of structural design, CEN: Brussels, pp. 87, 2002.

[7] ISO 13822, Bases for design of structures - Assessment of existing structures, ISO Geneva, pp. 44, 2010.

[8] ČSN 73 0038, Navrhování konstrukcí - Doplňující ustanovení pro hodnocení existujících konstrukci (Design of structures - Supplementary guidance for existing structures, in Czech), ÚNMZ: Prague, pp. 71, 2014.

[9] CIB, Guide for the Structural Rehabilitation of Heritage Buildings (CIB Publication 335), CIB: Rotterdam, pp. 48, 2010. 
[10] Holicky, M., Introduction to Probability and Statistics for Engineers, Springer-Verlag: Berlin, pp. 181, 2013.

[11] Kühn, B., Helmerich, R., Nussbaumer, A., Günther, H. \& Herion, S., Assessment of existing steel structures: Recommendations for estimation of remaining fatigue life, JRC: pp. 89, 2007.

[12] Holowaty, J.M. \& Wichtowski, B., Properties of structural steel used in earlier railway bridges. Structural Engineering International: Journal of the International Association for Bridge and Structural Engineering (IABSE), 23(4), pp. 512-518, 2013. DOI: $10.2749 / 101686613 X 13627347099999$.

[13] de Bouw, M., Wouters, I., Vereecken, J. \& Lauriks, L., Iron and steel varieties in building industry between 1860 and 1914 - A complex and confusing situation resolved. Construction and Building Materials, 23(8), pp. 2775-2787, 2009. DOI: 10.1016/j. conbuildmat.2009.03.009

[14] Heyde, S. \& Lindner, J., Investigations on historic grey cast-iron columns. Proc. EUROSTEEL 2008, eds. R. Ofner, D. Beg, J. Fink, R. Greiner \& H. Unterweger, ECCS Southampton: Brussels, pp. 1545-1550, 2008.

[15] Rondal, J. \& Rasmussen, K.J., On the Strength of Cast Iron Columns, Brookhaven National Laboratory, The University of Sydney, Department of Civil Engineering, Sydney, Australia, pp. 24, 2003.

[16] Rondal, J. \& Rasmussen, K.J.R., On the strength of cast iron columns. Journal of Constructional Steel Research, 60(9), pp. 1257-1270, 2004. DOI: 10.1016/j. jesr.2003.12.006

[17] Nadolski, V. \& Sykora, M., Uncertainty in resistance models for steel members. Transactions of the VSB - Technical University of Ostrava, Civil Engineering Series, 14(2), pp. 26-37, 2014. DOI: 10.2478/tvsb-2014-0028

[18] Nadolski, V. \& Sykora, M., Model Uncertainties in Resistances of Steel Members. Proc. ESREL 2015, eds. L. Podofillini, B. Sudret, B. Stojadinovic, E. Zio \& W. Kröger, Taylor and Francis/Balkema: Leiden, pp. 4189-4195, 2015. 